\title{
Accretion, retreat and transgression of coastal wetlands experiencing sea-level rise
}

Angelo Breda ${ }^{1}$, Patricia M. Saco ${ }^{1 *}$, Steven G. Sandi ${ }^{1}$, Neil Saintilan ${ }^{2}$, Gerardo Riccardi ${ }^{3}$, José F. Rodríguez $^{1^{*}}$

$5{ }^{1}$ School of Engineering and Centre for Water Security and Environmental Sustainability, The University of Newcastle, Callaghan 2308, Austra lia

2 Department of Environmenta1Sciences, Macquarie University, North Ryde 2109, Austra lia

${ }^{3}$ Department of Hydraulics and Resea rch Council of NationalUniversity of Rosario, Rosa rio 2000, Argentina

Correspondence to: Patricia M. Saco (patricia.saco@newcastle.edu.au), José F. Rodríguez (jose.rodriguez@newcastle.edu.au)

10 Abstract. The vulnerability of coastalwetlands to future sea-level rise (SLR) has been extensively studied in recent years, and models of coastal wetland evolution have been developed to assess and quantify the expected impacts. Coastal wetlands respond to SLR by vertical accretion and landward migration. Wetlands accrete due to their capacity to trap sediments and to incorporate dead leaves, branches stems and roots into the soil, and they migrate driven by the preferred inundation conditions in terms of sa linity and oxygen a vailability. Accretion and migration strongly interact and they both depend on water flow and

15 sediment distribution within the wetland, so wetlands under the same external flow and sediment forcing but with different configurations will respond differently to SLR. Analyses of wetland response to SLR that do not incorporate realistic consideration of flow and sediment distribution, like the bathtub approach, are likely to result in poor estimates of wetland resilience. Here, we investigate how accretion and migration processes affect wetland response to SLR using a computational framework that includes all relevant hydrodynamic and sediment transport mechanisms that affect vegetation and landscape dynamics, and it is efficient enough computationally to allow the simulation of long time periods. Our framework incorporates two vegetation species, mangrove and saltmarsh, and accounts for the effects of natural and manmade features like inner channels, embankments and flow constrictions due to culverts. We apply our model to simplified doma ins that represent four different settings found in coastalwetlands, including a case of a tidal flat free from obstructions or dra ina ge features and three other cases incorporating an inner channel, an embankment with a culvert, and a combination of inner channel, embankment and culvert. We use conditions typical of SE Australia in terms of vegetation, tidal range and sediment load, but we also analyse situations with three times the sediment load to assess the potential of biophysical feedbacks to produce increased accretion rates. We find that all wetland settings are unable to cope with SLR and disappear by the end of the century, even for the case of increased sediment load. Wetlands with good drainage that improves tidal flushing are more resilient than wetlands with obstacles that result in tidal attenuation, and can delay wetland submergence by 20 years. Results from a bathtub

30 model reveals systematic overprediction of wetland resilience to SLR: by the end of the century, half of the wetland survives with a typical sediment load, while the entire wetland survives with increased sediment load.

Keywords: coastalwetlands, sea-level rise, accretion, migration, hydrodynamic model, sediment transport model, mangrove, saltmarsh.

\section{Introduction}

The vulnerability of coastalwetlands to future sea-level rise has been extensively studied in recent years, and models of coa stal wetland evolution have been developed to assess and quantify the expected impacts (Alizad et al., 2016b;Belliard et al., 2016; Clough et al., 2016;D'Alpaos et al., 2011;Fagherazzi et al., 2012;Kirwan and Megonigal, 2013;Krauss et al., 2010;Lovelock et al., 2015b;Mogensen and Rogers, 2018;Rodriguez et al., 2017;Rogers et a1., 2012;Schuerch et al., 2018). 
associated with representing interactions at a variety of spatial and temporal scales. Coastal wetlands respond to SLR by vertical a ccretion and landward migration. Vertical accretion occurs due to the capa city of wetland vegetation to trap sediments and to incorporate dead leaves, branches stems and roots into the soil, building up their vertical elevation and counteracting submergence due to SLR. Landward migration is driven by the preferred inundation conditions of wetland vegetation, which is continuously moving up the wetland slope due to SLR. These two main processes interact, but they also integrate a number of biophysical exchanges that occur smaller scales. Accretion is a function of many other variables like the tidal regime, sediment a vailability and type of vegetation (Fa gherazzi et al., 2012;Lovelock et a1., 2015a). Vegetation preference is dicta ted by salinity, oxygen availability and the presence of phytotoxins in the soil (Bilskie et a1., 2016;Crase et a1., 2013). Studies show that different modelling a pproa ches used to address the interaction between these variables may lead to divergent results (Alizad et al., 2016a;Rogers et a1., 2013). For the sake of simplicity, some previous studies have adopted an approach where water levels throughout the wetland remain the same as those observed at the entrance, i.e. the bathtub approach (D'Alpaos et al., 2011; Kirwan and Guntenspergen, 2010;Kirwan et a1., 2010;Kirwan et al., 2016a;Lovelock et al., 2015b). Most of these bathtub model results show that vegetation in coastalareas can produce accretion rates similar to sea-level rise predictions, therefore maintaining their elevation in the tidal prism, except when tidal range and sediment supply are very low.

55 However, the projections of coa stal wetland resilience under high rates of SLR appears to be at odds with pa la eo-environmental reconstructions of wetland responses to rising seas during the early Holocene (Horton et al., 2018; Sa intilan et al., 2020). One explanation of this discrepancy is that models fail to reproduce the flow attenuation caused by the friction induced by substrate cover and specific wetland features like inner channels, embankments and flow constrictions (Hunt et al., 2015) and its effects on sediment availability, which may result in overestimation of wetland accretion rates (Rodriguez et al., 2017). Bathtub models do not provide information on flow discharges or velocities, so they need an independent specification of sediment concentration.

On the other hand, more detailed description of hydrodynamic and sediment transport mechanisms can be incorporated into the computations of wetland dynamics using conventional two or three dimensional flow and sediment transport models (Ganju et al., 2015;Lalimi et al., 2020;Temmerman et al., 2005). A detailed description of flow and sediment transport

65 processes can potentially result in a better estimation of wetland dynamics including accretion and migration processes, but implementation can be seriously limited by computational cost and da ta a vailability (Beudin et al., 2017).

Here, we investigate how accretion and migration processes a ffect wetland response to SLR using a computational framework that includes all relevant hydrodynamic and sediment transport mechanisms that affect vegetation and landscape dynamics, yet it is efficient enough to a llow the simulation of long time periods. The framework consists of a fast-performance quasi-2D

70 hydrodynamic model (Riccardi, 2000;Rodriguez et al., 2017) that we have extensively tested in wetlands (Rodriguez et al., 2017; Saco et al., 2019;:Sandiet al., 2018;Sandiet al., 2019;Sandiet a1., 2020a;Sandiet al., 2020b) and a sediment advection transport model (Garcia et al., 2015) that we couple with vegetation formulations for preference to tidal conditions to obtain realistic predictions of wetland accretion and migration under SLR. Our framework incorporates two vegetation species, mangrove and saltmarsh, and accounts for the effects of manmade features like inner channels, embankments and flow constrictions due to culverts. We apply our model to simplified domains that represent distinct areas within a real wetland, in which we are able to characterise the effects of particular na tural and manmade wetland features like vegeta tion types, culverts, embankments and channels.

Coastalwetlands a re found over a broad spectrum of geomorphological settings (Woodroffe et al., 2016) and undera diverse set of anthropogenic interventions (Temmerman and Kirwan, 2015). While our results strictly apply to a reas of our wetland in

80 Southeast Australia, each of our selected domains focusses on particular geomorphological characteristics that may a lso be present in other wetlands worldwide. We study wetland evolution on domains with no drainage network or manmade structures, which is relevant for some low-tide wetland environments where no human intervention has occurred (Leong et al., 2018; Oliver et al., 2012; Tabak et a1., 2016). We simulate the dynamics of internal channels, which can provide insight on 
wetlands studies with strong influence of natural channels (Reef et al., 2018; Silvestri et al., 2005) or manmade drainage channels (Manda et al., 2014). We carry-out experiments with embankments and culverts representing flood sheltered environments, which can resemble intentionalflood attenuation works for coastalprotection (Van Loon-Steensma et a1., 2015) or unintentional flood attenuation as the result of roads, tracks, pipes and other infrastructure typical of heavily humanoccupied coasts (Kirwan and Megonigal, 2013;Rodriguez et a1., 2017;Temmerman et al., 2003).

Also, and in order to make our results more widely relevant, we analyse the sensitivity of our predictions to the sediment load coming into the wetland by including sediment-poor and sediment-rich simulations. The incoming sediment load has been proposed as one of the main factor influencing the resilience of coastalwetlands to SLR (Lovelock et al., 2015a;Schuerch et al.,2018) and is one of the components of predictive wetland evolution models with more uncertainty, due both to our limited understanding of sediment-flow-vegetation processes and our inability to predict sediment loads in a changing future.

\section{Experimental design and methods}

\subsection{Design of simulations}

The flow in tidalwetlands can be quite complex because of the interaction of the tidal flow with naturaland manmade features like vegetation, topography, channels, culverts and embankments. For that rea son, results for a particular wetland may have limited applicability to another wetland with different features. In this contribution, we analyse some of the most common features of wetlands in isolation in order to ga in a better understanding of the contribution of each feature to the overall wetland response, and how it influences the response to sea-level rise. For that purpose, we study the response of wetlands with limited complexity using a state of the art ecogeomorphological model on four hypotheticaltidal flats that characterise specific areas of a typical SE Austra lian coastal wetland that we have studied before (Fig.1 a) (Rodriguez et al., 2017). Experiment 2 considers a consistently sloping tidal flat initially vegetated by mangrove, saltmarsh and freshwater vegetation, Experiment 3 incorporates a drainage channel $0.4 \mathrm{~m}$ deep and $5 \mathrm{~m}$ wide to the vegetated tidal flat, Experiment 4 includes an embankment with a culvert ( $0.4 \mathrm{~m}$ wide) in the middle of the vegetated flat, and Experiment 5 combines both a drainage channel and an embankment with a culvert. We also run an experiment (Experiment 1) using the bathtub a pproach, in which none of the above fea tures are taken into a ccount. These different setups can characterise different settings found in wetlands, but can also apply to different parts of a more complex wetland, as shown in Fig. 1b. In all experiments the tidal flat is $620 \mathrm{~m}$ long (main flow direction) and $310 \mathrm{~m}$ wide (cross-section), divided into $10 \mathrm{~m}$ by $10 \mathrm{~m}$ grid cells, with a gentle slope of $0.001 \mathrm{~m} / \mathrm{m}$. Boundary conditions include input tides described by a sinusoidal function with $1.3 \mathrm{~m}$ amplitude and 12-hour period, and a constant sediment concentration at the wetland inlet (Fig. 1c). In each experiment we tested wetland evolution under sea-level rise from 2000 to 2100 (high emissions scenario) considering two sediment input conditions, a low sediment supply representing current conditions and a high sediment supply. The high sediment supply condition simulations are justified due to the uncertainty of

115 climatic conditions and the possibility of increases in intensity of storm patterns in the area, which may result on increased sediment loads in the Hunter River. Sediment loads may also increase due to changes in land use practices (Rodriguez et al., 2020).

The sinusoidal tide represents conditions typicalof SE Austra lian estuaries (Rodriguez et al., 2017)and is repeated during the simulation period (100 years). However, the mean water level is gradually increased following the IPCC RCP 8.5 scenario of sea-level rise (Church et al., 2013) with an expected $0.74 \mathrm{~m}$ increase by year 2100 with respect to the levels in the year 2000. We use as a basis for our simulations the ecogeomorphological model(EGM) framework developed by Rodriguez et a1. (2017), but with the addition of a physically-based sediment transport formulation. This EGM framework has been extensively calibrated and tested in the Hunter River Estuary in Australia and, as such, vegetation functions and parameters correspond to 
local conditions. The framework couples multiple models to simulate interactions between overland flow hydrodynamics,

\subsection{Hydrodynamic model}

Water depth time series over the tidal flat are estimated using a finite-differences quasi-2D hydrodynamic model (Riccardi, 2000) that has been successfully applied to coastalwetlands (Rodriguez et a1., 2017; Sandiet al., 2018) and floodpla ins (Sandi et al., 2019; Sandi et al., 2020a; Sandi et al., 2020b;Saco et al., 2019). The model solves the shallow water equations using a cells scheme, in which cells are classified into tidal flat or channel categories to speed up computations. As previously expla ined, the doma ins of a ll experiments are $630 \mathrm{~m}$ long by $310 \mathrm{~m}$ wide, discretised into $10 \mathrm{mx} 10 \mathrm{~m}$ cells. Boundary conditions include water elevations at the tidal creek and no-flow at the lateral and landward boundaries. Because the domains are wide, the effects of lateral model boundaries are minimal.

The model solves for water elevations at cells and discharges between cells at each time step. Mass conservation is solved first to compute water surface eleva tions:

$A s_{i} \frac{d z_{i}}{d t}=\sum_{k=1}^{j} Q_{k, i}$

where $A s_{i}$ and $z_{i}$ are surface wetted area and water surface elevation at cell $i$, respectively and $Q_{k, i}$ are the discharges between cell $i$ and its $j$ neighbouring cells. Using the water surface elevations, the model then computes discharges between cells using the momentum or energy equation, depending on the particular characteristics of the connection between cells. For instance, the discharge between two cells on the vegetated tidal flat is computed as:

$Q_{k, i}=\frac{A_{k, i} R_{k, i}^{\frac{2}{3}}}{n_{k, i}}\left(\frac{z_{k}-z_{i}}{x_{k}-x_{i}}\right)^{\frac{1}{2}}$,

where $A_{k, i}, R_{k, i}$ and $n_{k, i}$ are respectively the cross-sectional va lues of a rea, wetted perimeter and Manning roughness computed as an average of the values at cells $k$ and $i$, and $x_{k}-x_{i}$ is the distance between cells. Based on Rodriguez et al. (2017) we a dopt roughness coefficients for mangrove and saltmarsh cells of $0.50 \mathrm{~s} / \mathrm{m}^{1 / 3}$ and $0.15 \mathrm{~s} / \mathrm{m}^{1 / 3}$, respectively. For freshwater and no-vegetated cells, the Manning's- $n$ is $0.12 \mathrm{~s} / \mathrm{m}^{1 / 3}$, while for channel cell it is $0.035 \mathrm{~s} / \mathrm{m}^{1 / 3}$. For cells in the channel, the full momentum equation is used to account fordynamic and backwater effects (Riccardi, 2000). If the domain includes a culvert at cell $i$, then the discharge between cells $k$ and $i$ is computed as:

$Q_{k, i}=\frac{(2 g) \frac{1}{2}\left(z_{k}-z_{i}\right)^{\frac{1}{2}}}{\left(\frac{1}{c_{d}^{2} A_{i}^{2}}-\frac{1}{A_{k}^{2}}\right)^{\frac{1}{2}}}$,

in which $A_{i}$ and $A_{k}$ are respectively the cross-sectional areas at the $i$ and $k$ cells and $C_{d}$ is a standard discharge coefficient for the culvert at cell $i$ adopted as 0.8 . Equation (3) considered the case of the culvert flowing under the influence of gravity. For pressurised conditions, a different equation is used (Riccardi, 2000)

The model equations are solved using an implicit method and a Newton-Raphson algorithm. The time step used in the model solution is $1 \mathrm{~s}$ to ensure numerical stability. Further explanation about the application of this model in a similar EGM framework can be found in Sandi et al. (2018).

\subsection{Vegetation model}

Vegetation in coastal wetlands is driven by the tidal regime, so we use water depth time-series to compute the mean depth below high tide, $D$, and the hydroperiod, $H$, on every cell as a descriptor of the tidal regime. These variables are the input for all the other models of the EGM framework. The first variable represents the average maximum water depth on spring tides. 
In this case we use a sinusoidal wave, so $D$ is the maximum depth. The hydroperiod accounts for the duration of the inundation period and is computed as the proportion of time during which a minimum water depth is present during the simulation time. The values of $H$ and $D$ define the suitable conditions for vegetation establishment and survival at each point in the wetland based on thresholds that have been tested for SE Australian estuaries (Rodriguez et al., 2017). Thus, the observed threshold applies to Avicennia marina (grey mangrove) and to a composition of saltmarsh species Sarcocornia quinqueflora and Sporobolus virginicus. Mangrove depends primarily on hydroperiod, requires frequent inundations and establishes in areas where $10 \%<H<50 \%$ and $D>0.2 \mathrm{~m}$, where $H$ is calculated as the fraction of time where the water depth is higher than or equal to $14 \mathrm{~cm}$, the typical height of the pneumatophores. Saltmarsh tolerates prolonged inundations and can survive in areas where $H<80 \%$, but cannot endure inundation depths above its height $(25 \mathrm{~cm})$ so we limit $D<0.25 \mathrm{~m}$. We consider that, if conditions suit both mangrove and saltmarsh, mangrove will expand over saltmarsh areas (Sa intilan et a1., 2014). In a reas not exposed to saltwater $(H=0 \%, D \sim 0 \mathrm{~m})$, we assume the presence of freshwater vegetation, and if none of the above conditions applies, areas are considered to be non-vegetated.

\subsection{Sediment model}

The original version of the framework used in the Hunter estuary applies a linear empirical relationship between average sediment concentration in the water column and the water depth. Here, we use a more physically based equation for fine sediment transport and deposition processes coupled to the hydrodynamic simulations. The sediment model solves the quasi2D continuity equation of suspended sediment neglecting horizontal diffusion (Garcia et al., 2015). The continuity equation for the $i$-th cell reads as follows:

$A s_{i} \frac{d(h C)_{i}}{d t}=A s_{i} \varphi_{i}+\sum_{k=1}^{j}(Q C)_{k, i}$,

where $h_{i}$ is the water depth of cell $i(\mathrm{~m}) ; C_{i}$ is the sediment concentration $\left(\mathrm{g} \mathrm{m}^{-3}\right), \varphi_{i}$ is the downward vertical flux of fine sediment $\left(\mathrm{g} \mathrm{m}^{-2} \mathrm{~s}^{-1}\right)$, and $C_{k, i}$ are the sediment concentrations in the $j$ neighbouring cells. For fine grained sediment typical of estuarine environments, the downward flux can be expressed as (Krone, 1962; Mehta and McAnally, 2008):

$\varphi_{i}=-w_{s}\left(1-\frac{\tau_{b i}}{\tau_{d}}\right) C_{i} ; \tau_{b}<\tau_{d}$,

where $w_{s}$ is the fall/settling velocity of suspended sediment particles $\left(\mathrm{m} \mathrm{s}^{-1}\right), \tau_{b i}$ is the magnitude of bed shear stress in cell $i$ $(\mathrm{Pa})$, and $\tau_{d}$ is the critical flow velocity for deposition ( $\left.\mathrm{Pa}\right)$. Velocities where converted to bed shear stresses using $\tau_{b i}=\rho C_{f} U_{i}^{2}$,

In equation (6) $\rho$ is the water density and $C_{f}$ is a friction coefficient set at 0.015 . The parameters $w_{s}$ and $\tau_{d}$ were varied to reproduce similar levels of accretion observed in the wetlands where the original modelling fra mework was applied (Rodriguez et al., 2017). The values obtained were $\tau_{d}=0.01 \mathrm{~Pa}$ and $w_{s}=2 \times 10^{-4} \mathrm{~m} / \mathrm{s}$, which are consistent with values reported by Best et al. (2018); Chen et al. (2010); Kirwan and Guntenspergen (2010); Larsen and Harvey (2010) and Temmerman et al. (2005). This modeldoes not have an erosion term, which is not a bad simplification overvegeta ted surfaces that receive flows that are typically very slow.

Equation (4) is solved using the same numerical scheme than the water mass conservation (equation 1) providing a time series of sediment concentrations in each cell of the domain. However, as the soil elevation model (next section) works at a larger time scale and requires the annualconcentration, $\bar{C}$, a weighted average is computed for each cell:

$\bar{C}=\frac{\sum_{t=0}^{M}\left(C_{t} \times h_{t}\right)}{\sum_{t=0}^{M} h_{t}}$,

195 where $t$ is the time in the hydrodynamic simulation with $M$ the final step, $C_{t}$ and $h_{t}$ are the sediment concentration and the water depth, respectively, at time $t$.

The sediment transport equation based on mass conservation (eq. 4) cannot be used in the case of the bathtub simulations because the bathtub model does not provide information on water discharge and velocity. For the bathtub simulations, we used 
the linear relation between water depth and concentration empirically developed by Rodriguez et al. (2017). Based on the measured data, the fitted equation is:

$\bar{C}=C_{\text {max }}(0.55 D+0.32)$,

where $\bar{C}$ is the average sediment concentration $\left(\mathrm{g} / \mathrm{m}^{3}\right)$, and $C_{\max }$ is the concentration at the wetland inlet.

This equation is much simpler and has different parameters than the sediment transport equation; however, for very simple flow conditions it should produce comparable results. We confirmed the suitability of the simple model by comparing EGM results using the bathtub approach (with the linear sediment relation) and a full hydrodynamic and sediment transport EGM over a smooth topography. Both the hydrodynamics and the resulting elevation changes of both models were very similar (See Figure S1 in Supplementary Materials).

\subsection{Soil elevation change model}

Our EGM framework adopts the model originally proposed by Morris et al. (2002) and later modified by Kirwan and

210 Guntenspergen (2010) to estimate the increase in soil elevation due to accretion as function of hydrodyna mic and ecological conditions. We first compute the biomass production, $B\left(\mathrm{~g} / \mathrm{m}^{2}\right)$, by using the parabolic equation:

$B=a D^{2}+b D+c$,

where $a, b$, and $c$ are parameters fitted to field data, for each vegetation type. Then, the surface elevation change rate, $d E / d t$ (m/year), is calculated using:

$215 \frac{d E}{d t}=\bar{C}(q+k B) D$,

where $q$ is a depositional parameterand $k$ is a vegetation sediment trapping coefficient. For all five parameters of equations (9) and (10) we used the values adopted in Rodriguez et al. (2017) and Sandi et al. (2018) (see Table 1) for an Australian wetland.

The EGM simulations use a yearly time-step, i.e. the computed biomass and accretion represent an average condition within this period. We choose a yearly time-step as vegetation dyna mics does not respond instantaneously to flow and depositional processes (Alizad et a 1., 2016b;Saco and Rodríguez, 2013;Schuerch et al., 2018). Our model does not account for erosion and diffusion processes and also does not take into account the redistribution of deposited sediment by waves. Because of that, the resulting accretion from equation (10) is noisy and vary considerably over very short distances. In order to work with a more realistic distribution of deposition over the tidal flat we smooth the topography by applying a very simple diffusion model. The diffusion model does not change the general trends of deposition and avoids localised peaks of excessive deposition.

\section{Results}

\subsection{Spatial patterns of accretion and vegetation}

In order to show the characteristic spatialpatterns of each of the typical cases analysed we first show in Figure 2 accumulated accretion $(\Delta E)$ and vegetation distribution in 2050 under the expected SLR scenario for each of the five numerical experiments, including the bathtub and the other four experiments that use a hydrodynamic and sediment transport (HST) models. Details on the temporalevolution of topography and vegetation for each of the experiments are provided later in the manuscript. Figure 2 shows that accumulated accretion is homogeneous in the transverse direction for the experiments without the channel (Fig. 2a,b,d), as there is no lateral flow and the changes in sedimentation occur in the longitudinal direction only. For the experiments with the central dra inage channel(Fig. $2 \mathrm{c}, \mathrm{e}$ ) there is a marked concentration of flow and sediment accumulation close to the channel. Some of the accumulated accretion patterns of the experiments with the channelpresented in Figure 2 are remarkably similar to the results from Chen et al. (2010) on a similar geometry. 
It can be seen from the figure that all experiments show a general decrease of accretion with distance to the tidal input (which can represent a tidal creek or the river), which is expected because the source of sediment is at the tidal input. However, each experiment has a characteristic elevation profile and vegetation distribution, and they are all quite different from the predictions of the bathtub model. Figure 2a shows that the bathtub experiment displays two depositional mounds, one at $300 \mathrm{~m}$ and the other at $500 \mathrm{~m}$ from the creek, which are due to the initial position of high biomass areas of mangrove and saltmarsh, respectively, (Figure 3a) as it will be explained later. The bathtub case has flood and ebb flows of the same duration, since there is no flow attenuation. This keeps the hydroperiod within a range that promotes mangrove establishment over most of the wetland. Saltmarsh is limited to the upper parts of the tidal flat.

245 The other simulations (Experiments 2 to 5) use the hydrodyna mic and sediment transport (HST) models instead of the ba thtub approximation. In these cases, accretion presents an exponential shape with a sharper decrease than the bathtub model, and vegetation establishment is strongly controlled by the effects of vegetation roughness, channeland culverts. In contrast to the bathtub model results, all HST simulations show mangrove dieback in lower areas, which is caused by a higher hydroperiod due to attenua ted ebb flows.

250 Experiment 2, with the undisturbed tidal flat (Figure 2b), shows the effect of hydraulic resistance due to the vegetation roughness only, which generates an elevation mound closer to the tidal input than the bathtub experiment. In Experiment 3 (Figure 2c), the inner channel increases the dra inage of the surrounding areas, thus reducing the hydroperiod in the vicinity of the channel and a llowing mangroves to persist close to the tidal creek. The channel also enhances sediment delivery farther from the tidal input, which causes an increase in accretion around the mid-point of the flat (300 $\mathrm{m}$ from the tidal creek).

However, this effect is concentrated near the channel and fades away as flow is directed into the tidal flat. In Experiment 4 (Figure 2d), the flow is restricted by an embankment and a culvert, so the hydroperiods in the upper wetland are higher. This effect reduces mangrove migration and its encroa chment on saltmarsh areas. In Experiment 5 with embankment and channel (Fig. 2e), the channel promotes mangrove landwards of the embankment, and also the stabilisation of saltmarsh areas in the upper sections of the tidal flat as they receive more sediment (Figure 2e).

\subsection{Evolution of accumulated accretion profiles}

Figure 3 shows the results of surface elevation change $(\Delta E)$ in each experiment for the years 2020,2040, 2060 and 2100 for low sediment input conditions (corresponding to contemporary rates in the Hunter estuary), in terms of accumulated accretion profiles a long the main flow direction. For the experiments with the centraldrainage channel(Experiments 3 and 5), we have included two profiles at different transverse locations, one close to the channeland one $150 \mathrm{~m}$ a way in the middle of the tidal

During the first two decades, the vegetation type plays an important role in the longitudinal distribution of the accumulated accretion profiles. By 2020 (first column of Figure 3) the profiles show a continuous decrease from the tidal input up to 300 to $350 \mathrm{~m}$ approximately, which coincides with the transition from mangrove to saltmarsh in the initial vegeta tion distributions (see Fig. 5 later in the manuscript). This occurs due to the dynamics of sediment transport (more deposition close to the tidal input) and also due to the reduction of the mangrove biomass a way from the tidal creek (reductions in $D$, see eqn. 10). The increase in $\Delta E$ at the transition is due to the saltmarsh having a higher biomass and trapping efficiency than mangrove at that particular value of $D$. Landward of the transition, $\Delta E$ decreases with decreases in saltmarsh biomass. This general dynamics is disrupted by the presence of the culvert because it limits the a mount of sediment reaching the upper a reas of the tidal flat. Changes in $\Delta E$ slow down after 2060 in all experiments except for the bathtub case. This is due to reductions in vegetation as most of the lower areas of the tidal flat have experienced submergence and vegetation loss. Small increases in $\Delta E$ occur in the upper areas in the cases in which the central channel promotes tidal flushing (Experiments 3 and 5), but this effect is concentrated in areas close to the channel. 
None of the experiments using the HST model produces $\Delta E$ results similar to the bathtub simulations. The experiment with the central channel(Experiment 3 ), presents values of $\Delta E$ near the channel that are close to the results of the bathtub simulation during the first years, but over time, the results diverge. The increased $\Delta E$ values are limited to areas next to the channel, and they quickly decline as the flow is directed into the tidal flat. In general, the outcomes from the HST model shows a reduction in the water levels and total accretion compared to the bathtub results. Furthermore, when the culvert is introduced in the simulation (Experiments 4 and 5), the main effect is a drastic reduction of $\Delta E$ in the upperareas of the domain.

Figure 3 results correspond to a situation with a low sediment input of $37 \mathrm{~g} / \mathrm{m}^{3}$, typical of current SE Australia conditions (Rodriguez et al., 2017). Similar patterns but with larger values of accumula ted accretion were obta ined for a higher sediment input of $111 \mathrm{~g} / \mathrm{m}^{3}$ (Figure S2 in Supplementary Materials).

The reduction in accretion in the experiments that consider the actual features of the wetland can be better apprecia ted in Figure 4 , in which we compare domain-average $\Delta E$ of all experiments over time. Figure 4 includes results for a low sediment input of $37 \mathrm{~g} / \mathrm{m}^{3}$ (Figure $4 \mathrm{a}$ ) and for a high sediment input of $111 \mathrm{~g} / \mathrm{m}^{3}$ (Figure $4 \mathrm{~b}$ ). The figure also includes the values of mean sealevel for each year to give an idea of the submergence conditions in the wetlands.

There is a clear difference between the accretion generated in the bathtub simulation, and the rest of the experiments. In our simulations, accretion is a function of sediment concentration and depth below mean high tide $(D)$. The bathtub assumption overpredicts both inputs over the entire domain, thus generating higher accretion values. In all HST simulations, the combination of a reduction in $D$ because of flow attenuation and the exponential decay of sediment concentration results in from the bathtub is about 2 times the values of all the other experiments, increasing to more than 3 times by 2100 . In the simulations with high sediment input (Figure $4 b$ ), the accumulated accretion of bathtub simulations are 2.5 and 4 times the values of the rest of the experiments for 2050 and 2100, respectively. The experiments with the HST simulations present diferent levels of attenuation and accordingly different accretion levels. The lowest accretion correspond to the highly attenuated case with embankment and culvert (Exp. 4), whereas the highest accretion occur in the case of the central channel (Exp. 3) that experiences increased drainage and thus less attenuation. The cases of the tidal flat with no structures (Exp. 2) and of the embankment with inner channel(Exp.5) have intermediate levels of attenuation and accretion.

All simulations show a strong elevation deficit (i.e. the difference between the rate of sea level rise and wetland accretion rate $\mathrm{d} E / \mathrm{d} t$ ), as none of the experiments predict that the tidal flat is capable to keep pace with SLR. For the low-sediment conditions,

305 by 2050 the elevation deficit of the bathtub simulation is $5.5 \mathrm{~mm} / \mathrm{yr}$, while the rest of the experiments predict an elevation deficit of about $7 \mathrm{~mm} / \mathrm{yr}$. Over time, the elevation deficits increase and by 2100 the bathtub prediction reach a value of 9.5 $\mathrm{mm} / \mathrm{yr}$ and the HST simulations a value of $12 \mathrm{~mm} / \mathrm{yr}$.

Increa sing the sediment input concentration considerably changes the accretion capacity of the tidal flat, particularly according to the bathtub results. Bathtub simulations predict that the tidal flat is able to accrete in a rate that almost match the changes in

310 sea level, so the wetland survives sea-level rise. Accretion for all other experiments are moderate, with the experiments that have the centralchannel(Experiments 3 and 5) responding more effectively to the increa sed sediment and accreting more than the other experiments (Exp. 2 and 4). Compared to the low sediment conditions, elevation deficits of the bathtub predictions reduce to $3 \mathrm{~mm} / \mathrm{yr}$ and $5.5 \mathrm{~mm} / \mathrm{yr}$ by 2050 and 2100 , respectively, while in the other experiments those values increase to about $6 \mathrm{~mm} / \mathrm{yr}$ and $10 \mathrm{~mm} / \mathrm{yr}$

315 The structures included in the simulations have a clear effect on the average $\Delta E$. The inner channel promotes a ccretion further inland, as it conveys more water and sediment to those areas away from the tidal input. Compared to the tidal flat free of structures (Experiment 2) the inclusion of the channel (Experiment 3 ) is responsible for an increase in wetland accumulated accretion of about $50 \%$. The opposite effect is observed when the embankment with culvert is introduced, as it a ttenuates and reduces the water and sediment flow into the upper part of the wetland. Compa ring results for the tidal flat without (Experiment 2) and with (Experiment 4) embankment and culvert, we can observe a reduction on wetland accumulated accretion of $25 \%$. 
The introduction of a drainage channel together with the embankment and culvert (Experiment 5) represents an intermediate situation in which the increased flushing effect of the channel and the attenuating effect of the embankment and culvert partially compensate.

In Figure 4a we have also included the average accumulated accretion for the entire wetland site (Area E in Figure 1b) using information from Rodriguez et al. (2017) and (Sandi et al., 2018). Rodriguez et al. (2017) applied a similar EGM formulation to Area E (Fig.1) to assess the effect of attenuation on wetland evolution under SLR considering typical $\left(37 \mathrm{mg} / \mathrm{m}^{3}\right)$ and increased $\left(111 \mathrm{mg} / \mathrm{m}^{3}\right.$ ) sediment conditions. (Sandi et al., 2018) further studied the effects of tidal restrictions at the wetland inlet considering typical sediment loads. The values included in the figure correspond to a verage accumulated accretion over the entire wetland at 2050 and 2100 for low sediment load with and without tidal restrictions (Figure 4a) and for high sediment load without restrictions (Figure 4b). The figures shows that the simulations without tidal restricions result in values of accumulated accretion similar to the experiment with low attenuation (Experiments 3 and 5) for both low and high sediment loads, while predictions of accumulated accretion including tidal restrictions are closer to the experiment with high attenuation (Experiments 2 and 4$)$.

\subsection{Changes in vegetation}

The interactions between sea-level rise, accretion and vegetation changes are complex because vegetation not only responds to vertical elevation changes but also migrates inland. In order to obtain a clear picture of the vegetation changes over time, we simplified two dimensional vegetation maps (i.e., Figure 2) into a one-dimensional representation. The vegetation type at a given distance from the tidal input was determined by selecting the predominant (higher occurrence) vegetation in the transverse direction. Figure 5 shows snapshots of the predominant vegetation every 20 years. As already explained, in the

340 simulations with embankment and culvert (Experiments 4 and 5), the structures are located at $310 \mathrm{~m}$ from the tidal input. The conditions at the beginning of the simulation (Figure 5a) for experiments 1,2, and 3 show mangrove occupying approximately the lower $400 \mathrm{~m}$ of the tidal flat and saltmarsh the next $200 \mathrm{~m}$ upland. For experiments 4 and 5 the presence of the embankment reduces hydroperiods in the upper areas, constraining mangrove to the lower $310 \mathrm{~m}$. The embankment also limits the extent of inundation in the upperareas, reducing the extent of the saltmarsh to about $100 \mathrm{~m}$ from the embankment.

345 After 20 years (Figure 5b) the simulations show mangrove encroachment on saltmarsh experiments 1, 2 and 3. The upstream mangrove edge moves up to $50 \mathrm{~m}$, forcing saltmarsh occurrence in areas further than $300 \mathrm{~m}$ from the tide input creek. In experiments 4 and 5 the embankment halts mangrove migration and increases in inundation of upper areas promote saltmarsh increase. Overall, wetland area increases due to mangrove expansion (Exp. 1, 2 and 3) or to saltmarsh expansion (Exp. 4 and $5)$.

350 By 2040 (Figure 5c), mangrove has encroached further on saltmarsh in experiments 1, 2 and 3, resulting in saltmarsh squeeze at the upper end due to the landward boundary of the computational domain. Experiments 4 and 5 show very minor encroachment of mangrove on saltmarsh, which is able to migrate landward. Total wetland area remains approximately unchanged for experiments 1, 2 and 3, while it keeps increa sing in experiments 4 and 5 . Some areas of mudflat start appearing in the HST experiments due to extended hydroperiods.

355 Twenty years later, in 2060 (Figure 5d), the MSL is about $30 \mathrm{~cm}$ higher than in 2000 and we can see considerable mudflat areas in all experiments except for the bathtub simulations (experiment 1), which presnts a uniform coverage of mangrove over the entire domain. Saltmarsh is totally absent in experiments 1,2 and 3 due to mangrove encroachment but still remains almost unchanged in experiments 4 and 5. All experiments except the bathtub simulations show decrea ses in wetland extent, mostly due to saltmarsh dissaparance in experiments 2 and 3 and to mangrove squeeze in experiments 4 and 5 .

360 From 2080 on (Figures 5e,f), a rapid retreat of the remaining wetland can be observed in all experiments. The retreat occurs faster for the experiments with the embankment, resulting in totalwetland disappearance by 2100 . The rest of the experiments still show some remnant mangrove areas by 2100 , which are only significant $(40 \%)$ in the case of the bathtub simulations. 
The same trend of increase in wetland a rea in the first 20 years of simulation, followed by a continuous decrease starting at 40 years and ending at 100 years with almost complete wetland disappearance under the same sea level rise trajectory was observed by Rodriguez et al. (2017) and Sandi et al. (2018). Sandi et al. (2018) also reported larger wetland losses for their experiments with tidal restrictions at the entrance when compared to the case without restrictions.

The same analysis of vegetation evolution for the high sediment input scenario is presented in Figure 6. With increased sediment, the patterns of vegetation change remain remarkably similar to the patterns observed in Figure 5 for the low sediment conditions, with exception of the bathtub simulations (Experiment 1). Compared to Figure 5, the bathtub results indicate that saltmarsh is able to remain in the upper wetland areas for longer (until 2060) and that mangrove does not retreat, resulting in no wetland loss after 100 years of simulation. The other experiments without embankment ( 2 and 3 ) show a slightly slower retreat of both mangrove and saltmarsh than in Figure 5, while the experiments with the embankment show almost the same behaviour as the in the case of low sediment. Some of experiments in Figure 6 show localised mangrove areas that tend to establish and persist close to the tidal creek.

\section{Discussion}

The interactions between all the processes related to the dynamic of coastal wetlands are quite complex (Fagherazzi et al., 2012;Reef et al., 2018; Sa intilan et a1., 2014), which makes the bathtub a ssumption limited for most applications. Places with multiple vegetation species (Cahoon et al., 2011;Rogers et al., 2006) and an intertwined channel network (D'Alpaos, 2011) present a strong heterogeneity of saltwater exposure and sediment delivery to the overbank areas that need a detailed description of flow and sediment processes (see a lso Coleman et al., 2020). Artificial structures constraining flow and sediment modify accretion rates (Bella fiore et a1., 2014;Cahoon et al., 2011) and thus wetland evolution (Rodriguez et al., 2017; Sandi et al., 2018). Even though our experimentaldesign focused on simplified setups, these setups comprise typicalwetland features and include most of the complex processes and interactions.

Our results indicate that wetlands do not cope with SLR for the simulated conditions corresponding to a high emissions climate change scenario. This result was not surprising for the low sediment situation, as the inability of sediment-poor coastal wetlands to survive high levels of SLR due to low accretion rates has been reported before (Kirwan et al., 2010;Lovelock et al., 2015b;Rodriguez et al., 2017; Sandiet al., 2018; Schuerch et al., 2018). However, the results for high sediment load seem to challenge some previous studies highlighting the potential of byophysical feedbacks to produce accretion rates compa rable to SLR (D'Alpaos et a1., 2007;Kirwan and Murray, 2007;Kirwan et al., 2016b;Mudd et al., 2009;Temmerman et a1., 2003) . In our case, the biophysical feedbacks with a high sediment load produced wetland accretion rates similar to SLR rates only for the bathtub simulation.

Analysis of accretion rates indicate that all experiments start with similar rates in the vegetated areas, with about $2.5 \mathrm{~mm} / \mathrm{yr}$ and $7.5 \mathrm{~mm} / \mathrm{yr}$ in the low and high sediment situation, respectively. For the low sediment case, the initial value compared very well with historic values for SE Australian conditions measured by Howe et al. (2009) and Rogers et al. (2006). For the high sediment case, an increase of the accretion value by a factor of three seems rea sonable considering an increase of the sediment load by a factor of three (from $37 \mathrm{~g} / \mathrm{m}^{3}$ to $111 \mathrm{~g} / \mathrm{m}^{3}$ ). Those starting values of accretion rema in at a pproxima tely the same level over most of the time for the bathtub simulations, while they decrease for the HST simulations. The decrease is more marked for Exps. 2 and 4 (which reach a value of about 1 to $1.5 \mathrm{~mm} / \mathrm{yr}$ by 2050), than for the simulations with inner channelExps. 3 and 5 (which attain values of $2 \mathrm{~mm} / \mathrm{yr}$ and $4 \mathrm{~mm} / \mathrm{yr}$ by 2050 for low and high sediment conditions, respectively). The reduction of the magnitude of the biophysical feedbacks over time is due to the continuous upland migration of vegetation, which colonises upper areas with comparatively less water depth and sediment supply (see also Sandi et al. (2018)). The bathtub model predicts less migration and higher depths, so it consistently overestimates accretion rates. 
Despite having reduced accretion rates when compared to the bathtub simulations, the HST simulations still show a noticeable difference in elevation ga ins depending on the sediment supply levels. Compared to the low sediment case, the high sediment supply case results in about twice the a vera ge accumulated accretion (Figure 4). However, analysis of vegetation changes over time for low (Figure 5) and high (Figure 6) sediment loads reveal minimum differences between them. For a more detailed analysis we can look at the vegetation evolution in terms of wetland area (mangrove and saltmarsh), wetland retreat (position of the seaward edge) and wetland transgretion (position of the landward edge), as presented in Figure 7 .

Figure 7a shows that the wetland extent predicted using the bathtub approach (Exp. 1) is affected by the sediment load, with only the low sediment condition resulting in a sharp decay in extent after 2060/70. The diference in extent is due to the vegetation retreat in the low sediment case, which does not occur in the high sediment case (Figure 7b). Wetland extent values for the HST simulations are not greatly a ffected by the sediment load, and they are much smaller than the values predicted by the bathtub (Figure 7a). Wetland retreat starts first in the experiments without the channel(Exps. 2 and 4 ) and about 20 years later in the experiments with the channel(Exps. 3 and 5) due to increased drainage. Once the retreat starts, it occurs faster in

415 the experiments with the embankment (Exps. 4 and 5) that delays the ebb flows and increases hydroperiods in the lower wetland areas.

Wetland transgression is not affected by the sediment conditions (Figure 7c) because of the limited amount of sediment that reaches the upper wetland areas. Transgression starts later in the experiments with the embankment (Exps. 4 and 5) because of the reduced depths and sediment loads in the upper wetland areas. The presence of the channel (Exp. 3 and 5) results in earlier but more gradualtransgression compared to setups with no drainage structure (Exp. 2 and 4).

It is clear from the analysis of Figure 7 that even though the increase in sediment load generates about twice the accretion, this extra elevation is not sufficient to prevent wetland submergence. Figure 4 suggests that accretion rates of four times the historic values or more are needed for the wetlands to be able to cope with SLR.

Although the simulations carried out in this study were conducted on simplified domains, the features included are present in many coastal areas around the world an thus have wider implications. Our bathtub results for low sediment conditions predicting an initial increase early in the century and then a decrease after 2060 agree with previous bathtub model predictions (Lovelock et al., 2015b;Rogers et al., 2012;Schuerch et al., 2018). However, using the HST framework our predictions indicate that the decrease may start as early as 2030 for wetlands with tidal range close to $1.3 \mathrm{~m}$ (as represented in our study), over a wide range of sediment loads. We can expect that this accelerated wetland loss will a ffect many parts of the world, particularly in areas with micro to meso tidal range and heavily developed coasts, like eastern Australia (Williams and Watford, 1997), parts of eastern US (Crain et a l., 2009), western US (Thorne et al., 2018) eastern China (Tian et al., 2016) and western Europe (Gibson et al., 2007). In these environments, attenuation can be important due to man-made structures, and transgression may be limited by development (Doody, 2013; Geselbracht et a1., 2015; Kirwan and Megonigal, 2013), so we can expect a behaviour closer to that of experiments 4 and 5. On the other hand, wetlands with dense drainage networks like the Venice Lagoon in Ita ly (Silvestri et a l., 2005), the Scheldt Estuary in the Netherlands (Temmerman et a 1., 2012), the North Inlet in South Carolina, US (Morris et al., 2005), would probably behave similarly to experiment 3 and experience comparatively less loss.

\section{Conclusion}

We conducted detailed numerical experiments on the response to SLR of four different typical coastal wetlands settings, including the case of a vegetated tidal flat free from obstructions and drainage features, and three other settings that included an inner channel, an embankment with a culvert, and a combination of inner channel, embankment and culvert. We also included an experiment using a simple bathtub approach, in which none of the features (vegetation, channels, culverts) are considered. We used conditions typical of SE Australia in terms of vegetation, tidal range and sediment load, but we also 
analysed simulations with an increased sediment load to assess the potential of biophysical feedbacks to enhance accretion rates.

445 We found that the distinct patterns of flow and sediment redistribution obtained from these simulations result in increased wetland vulnerability to SLR when compared to predictions using the simple bathtub approach. Changes in elevation due to accretion were between $10 \%$ and $50 \%$ of those obtained from bathtub predictions, and wetland retreat and reduction of wetland extent started 20 to 40 years earlier than for the case of the bathtub simulations, depending on wetland setting. Transgression for all settings was delayed with respect to the bathtub predictions and was limited by the presence of a hard barrier at the upland end.

The simulations using the full hydrodynamic and sediment transport dynamic models indicated that wetlands with good drainage (e.g. including an inner channel) were more resilient to SLR, displaying more accretion, a later retreat and reduction of wetland area and an increased transgression when compared with wetlands with strong flow impediments (e.g. including an embankment).

Incresing the sediment load delivered to the wetlands by a factor of three increased the accretion of all wetland settings by a factor of two. However, this extra elevation was not enough to prevent wetland submergence, as predictions of wetland evolution were very similar for low and high sediment conditions. Based on our results, we estimate that accretion rates of four times the typical historic values or more would be needed for these wetlands to cope with SLR.

Even though the characteristics of the wetlands studied here correspond mainly to SE Australian conditions, our results have a wider relevance because they clearly link the capacity of wetlands to accrete and migrate upland, the two mechanisms by which wetlands can ga in elevation and keep up with SLR. Failure to consider the spatialcoevolving nature of flow, sediment, vegetation and topographic features can result in overestimation of wetland resilience. Our results reconcile the wide discrepancy between upper thresholds of wetland resilience to sea-level rise in previous modelling studies with those emerging from palaeo-stratigraphic observations.

Data availability. Upon acceptance of the manuscript, the hydrodynamic modeland simulation results will be available from the corresponding authors on request.

Competing interests. The authors declare that they have no conflict of interest.

Author contribution. A.B., P.M.S. and J.F.R. designed the study. A.B. calibrated and fitted the models and run the simula tions. A.B., J.F.R., P.M.S., S.S., G.R. and N.S. analysed the results. A.B., P.M.S. and J.F.R. wrote the paper with substantial input from all co-authors.

Acknowledgements. P.M.S. acknowledges support from the Australian Research Council (grant FT140100610). A.B. was supported by a University of Newcastle $\mathrm{PhD}$ scholarship.

\section{References}

Alizad, K., Hagen, S. C., Morris, J. T., Bacopoulos, P., Bilskie, M. V., Weishampel, J. F., and Medeiros, S. C.: A coupled, two-dimensional hydrodynamic-marsh model with biological feedback, Ecol Model, 327, 29-43, 480 10.1016/j.ecolmodel.2016.01.013,2016a.

Alizad, K., Hagen, S. C., Morris, J. T., Medeiros, S. C., Bilskie, M. V., and Weishampel, J. F.: Coastal wetland response to sea-level rise in a fluvial estuarine system, Earths Future, 4, 483-497, 10.1002/2016ef000385, 2016b.

Bellafiore, D., Ghezzo, M., Tagliapietra, D., and Umgiesser, G.: Climate change and artificial barrier effects on the Venice Lagoon: Inundation dynamics of salt marshes and implications for halophytes distribution, Ocean Coast Manage, 100, 101-

$115,10.1016 /$ j.ocecoaman.2014.08.002,2014. 
Belliard, J. P., Di Marco, N., Carniello, L., and Toffolon, M.: Sediment and vegetation spatialdynamics facing sea-level rise in microtidal salt marshes: Insights from an ecogeomorphic model, Adv Water Resour, 93, 249-264, 10.1016/j.advwatres.2015.11.020,2016.

Best, Ü. S. N., Van der Wegen, M., Dijkstra, J., Willemsen, P. W. J. M., Borsje, B. W., and Roelvink, D. J. A.: Do salt marshes

490 survive sea level rise? Modelling wave action, morphodynamics and vegetation dynamics, Environ Modell Softw, 109, 152166, https://doi.org/10.1016/j.envsoft.2018.08.004, 2018.

Beudin, A., Kalra, T. S., Ganju, N. K., and Warner, J. C.: Development of a coupled wave-flow-vegetation interaction model, Computers \& Geosciences, 100, 76-86, https://doi.org/10.1016/j.cageo.2016.12.010, 2017.

Bilskie, M. V., Hagen, S. C., Alizad, K., Medeiros, S. C., Passeri, D. L., Needham, H. F., and Cox, A.: Dynamic simulation

495 and numerical analysis of hurricane storm surge under sea level rise with geomorphologic changes along the northern Gulf of Mexico, Earths Future, 4, 177-193,10.1002/2015ef000347, 2016.

Cahoon, D. R., Perez, B. C., Segura, B. D., and Lynch, J. C.: Elevation trends and shrink-swell response of wetland soils to flooding and drying, Estuar Coast Shelf S, 91, 463-474, 10.1016/j.ecss.2010.03.022,2011.

Chen, S. N., Geyer, W. R., Sherwood, C. R., and Ralston, D. K.: Sediment transport and deposition on a river-dominated tidal

500 flat: An idealized model study, J Geophys Res-Oceans, 115, Artn C10040

$10.1029 / 2010 \mathrm{jc} 006248,2010$.

Church, J. A., Clark, P. U., Cazenave, A., Gregory, J. M., Jevrejeva, S., Levermann, A., Merrifield, M. A., Milne, G. A., Nerem, R. S., Nunn, P. D., Payne, A. J., Pfeffer, W. T., Stammer, D., and Unnikrishnan, A. S.: Sea Level Change, in: Climate Change 2013: The Physical Science Basis. Contribution of Working Group I to the Fifth Assessment Report of the

505 Intergovernmental Panel on Climate Change, edited by: Stocker, T. F., Qin, D., Plattner, G.-K., Tignor, M., Allen, S. K., Boschung, J., Nauels, A., Xia, Y., Bex, V., and Midgley, P. M., Cambrige University Press, Cambridge, UK and New York, USA, 1137-1216,2013.

Clough, J., Polaczyk, A., and Propato, M.: Modeling the potentialeffects of sea-level rise on the coast of New York: Integrating mechanistic accretion and stochastic uncertainty, Environ Modell Softw, 84, 349-362, 10.1016/j.envsoft.2016.06.023,2016.

510 Crain, C. M., Halpern, B. S., Beck, M. W., and Kappel, C. V.: Understanding and Managing Human Threats to the Coastal Marine Environment, Year in Ecology and Conservation Biology 2009, 1162, 39-62, 10.1111/j.1749-6632.2009.04496.x, 2009.

Crase, B., Liedloff, A., Vesk, P. A., Burgman, M. A., and Wintle, B. A.: Hydroperiod is the main driver of the spatialpattem of dominance in mangrove communities, Global Ecol Biogeogr, 22, 806-817, 10.1111/geb.12063, 2013.

515 D'Alpaos, A., Lanzoni, S., Marani, M., and Rinaldo, A.: Landscape evolution in tidal embayments: Modeling the interplay of erosion, sedimentation, and vegetation dynamics, J Geophys Res-Earth, 112, Artn F01008 10.1029/2006jf000537,2007.

D'Alpaos, A.: The mutual influence of biotic and abiotic components on the long-term ecomorphodynamic evolution of saltmarsh ecosystems, Geomorphology, 126, 269-278,10.1016/j.geomorph.2010.04.027,2011.

520 D'Alpaos, A., Mudd, S. M., and Carniello, L.: Dynamic response of marshes to perturbations in suspended sediment concentrations and rates of relative sea level rise, J Geophys Res-Earth, 116, Artn F04020

10.1029/2011jf002093,2011.

Doody, J. P.: Coastal squeeze and managed rea lignment in southea st England, does it tell us anything about the future?, Ocean Coast Manage, 79, 34-41, 10.1016/j.ocecoaman.2012.05.008,2013.

525 Fagherazzi, S., Kirwan, M. L., Mudd, S. M., Guntenspergen, G. R., Temmerman, S., D'Alpaos, A., van de Koppel, J., Rybczyk, J. M., Reyes, E., Craft, C., and Clough, J.: Numerical Models of Salt Marsh Evolution: Ecological, Geomorphic, and Climatic Factors, Rev Geophys, 50, Artn Rg1002

$10.1029 / 2011 \operatorname{rg} 000359,2012$.

Ganju, N. K., Kirwan, M. L., Dickhudt, P. J., Guntenspergen, G. R., Cahoon, D. R., and Kroeger, K. D.: Sediment transport-

530 based metrics of wetland stability, Geophys Res Lett, 42, 7992-8000,10.1002/2015gl065980, 2015.

Garcia, M. L., Basile, P. A., Riccardi, G. A., and Rodriguez, J. F.: Modelling extraordinary floods and sedimentological processes in a large channel-floodplain system of the Lower Parana River (Argentina), Int J Sediment Res, 30, 150-159, 10.1016/j.jijsrc.2015.03.007,2015.

Geselbracht, L. L., Freeman, K., Birch, A. P., Brenner, J., and Gordon, D. R.: Modeled Sea Level Rise Impacts on Coastal

535 Ecosystems at Six Major Estuaries on Florida's Gulf Coast: Implications for Adaptation Planning, Plos One, 10, ARTN e0132079

10.1371/journal.pone.0132079,2015.

Gibson, R., Atkinson, R., Gordon, J., Editors, T., In, F., Airoldi, L., and Beck, M.: Loss, Status and Trends for CoastalMarine Habitats of Europe, An Annual Review, 45, 345-405, 10.1201/9781420050943.ch7,2007.

540 Horton, B. P., Shennan, I., Bradley, S. L., Cahill, N., Kirwan, M., Kopp, R. E., and Shaw, T. A.: Predicting marsh vulnerability to sea-level rise using Holocene relative sea-level data, Nat Commun, 9, ARTN 2687 $10.1038 / \mathrm{s} 41467-018-05080-0,2018$.

Howe, A. J., Rodriguez, J. F., and Saco, P. M.: Surface evolution and carbon sequestration in disturbed and undisturbed wetland soils of the Hunterestuary, southeast Austra lia, Estuar Coast Shelf S, 84, 75-83, 10.1016/j.ecss.2009.06.006,2009.

545 Hunt, S., Bryan, K. R., and Mullarney, J. C.: The influence of wind and waves on the existence of stable intertidal morphology in meso-tidalestuaries, Geomorphology, 228, 158-174, 10.1016/j.geomorph.2014.09.001,2015.

Kirwan, M. L., and Murray, A. B.: A coupled geomorphic and ecological model of tidal marsh evolution, P Natl Acad Sci USA, 104, 6118-6122, 10.1073/pnas.0700958104,2007. 
Kirwan, M. L., and Guntenspergen, G. R.: Influence of tidal range on the stability of coastalmarshland, J Geophys Res-Earth,

550 115, Artn F02009

10.1029/2009jf001400, 2010.

Kirwan, M. L., Guntenspergen, G. R., D'Alpa os, A., Morris, J. T., Mudd, S. M., and Temmerman, S.: Limits on the adaptability of coastalmarshes to rising sea level, Geophys Res Lett, 37, Artn L23401

$10.1029 / 2010 \mathrm{gl045489,2010.}$

555 Kirwan, M. L., and Megonigal, J. P.: Tidal wetland stability in the face of human impacts and sea-level rise, Nature, 504,5360, 10.1038/nature12856,2013.

Kirwan, M. L., Temmerman, S., Skeehan, E. E., Guntenspergen, G. R., and Fagherazzi, S.: Overestimation of marsh vulnerability to sea level rise, Nat Clim Change, 6, 253-260,10.1038/Nclimate2909,2016a.

Kirwan, M. L., Walters, D. C., Reay, W. G., and Carr, J. A.: Sea level driven marsh expansion in a coupled model of marsh

560 erosion and migration, Geophys Res Lett, 43, 4366-4373, 10.1002/2016gl068507,2016b.

Krauss, K. W., Cahoon, D. R., Allen, J. A., Ewel, K. C., Lynch, J. C., and Cormier, N.: Surface Elevation Change and Susceptibility of Different Mangrove Zones to Sea-Level Rise on Pacific High Islands of Micronesia, Ecosystems, 13, 129$143,10.1007 / \mathrm{s} 10021-009-9307-8,2010$.

Krone, R. B.: Flume studies of the transport of sediment in estua rial shoaling processes: Final report, University of Ca lifornia,

565 Berkeley, CA, 1962.

Lalimi, Y., Marani, M., Heffernan, J. B., D'Alpaos, A., and Murray, A. B.: Watershed and ocean controls of salt marsh extent and resilience, Earth Surf Proc Land, n/a, 10.1002/esp.4817,2020.

Larsen, L. G., and Harvey, J. W.: How Vegetation and Sediment Transport Feedbacks Drive Landscape Change in the Everglades and Wetlands Worldwide, Am Nat, 176, E66-E79, 10.1086/655215,2010.

570 Leong, R. C., Friess, D. A., Crase, B., Lee, W. K., and Webb, E. L.: High-resolution pattern of mangrove species distribution is controlled by surface elevation, Estuar Coast Shelf S, 202, 185-192, 10.1016/j.ecss.2017.12.015,2018.

Lovelock, C. E., Adame, M. F., Bennion, V., Hayes, M., Reef, R., Santini, N., and Cahoon, D. R.: Sea level and turbidity controls on mangrove soil surface elevation change, Estuar Coast Shelf S, 153, 1-9, 10.1016/j.ecss.2014.11.026,2015a.

Lovelock, C. E., Cahoon, D. R., Friess, D. A., Guntenspergen, G. R., Krauss, K. W., Reef, R., Rogers, K., Saunders, M. L.,

575 Sidik, F., Swales, A., Saintilan, N., Thuyen, L. X., and Triet, T.: The vulnerability of Indo-Pacific mangrove forests to sealevel rise, Nature, 526, 559-U217, 10.1038/nature15538,2015b.

Manda, A. K., Giuliano, A. S., and Allen, T. R.: Influence of artificial channels on the source and extent of saline water intrusion in the wind tide dominated wetlands of the southern Albemarle estuarine system (USA), Environ Earth Sci, 71, 44094419, 10.1007/s12665-013-2834-9, 2014.

580 Mehta, A. J., and McAnally, W. H.: Chapter 4: Fine-grained sediment transport, in: Sedimentation Engineering: Processes, Management, Modeling and Practice, edited by: Garcia, M. H., ASCE manuals and reports on engineering practice, Reston, VA, 2008.

Mogensen, L. A., and Rogers, K.: Validation and Comparison of a Model of the Effect of Sea-LevelRise on CoastalWetlands, Sci Rep-Uk, 8, ARTN 1369

585 10.1038/s41598-018-19695-2,2018.

Morris, J. T., Sundareshwar, P. V., Nietch, C. T., Kjerfve, B., and Cahoon, D. R.: Responses of coastalwetlands to rising sea level, Ecology, 83, 2869-2877, Doi 10.2307/3072022,2002.

Morris, J. T., Porter, D., Neet, M., Noble, P. A., Schmidt, L., Lapine, L. A., and Jensen, J. R.: Integrating LIDAR elevation data, multi-spectralimagery and neuralnetwork modelling for marsh characterization, Int J Remote Sens, 26, 5221-5234, Doi

$59010.1080 / 01431160500219018,2005$.

Mudd, S. M., Howell, S. M., and Morris, J. T.: Impact of dynamic feedbacks between sedimentation, sea-level rise, and biomass production on near-surface marsh stratigraphy and carbon accumulation, Estuar Coast Shelf S, 82, 377-389, 10.1016/j.ecss.2009.01.028,2009.

Oliver, T. S. N., Rogers, K., Chafer, C. J., and Woodroffe, C. D.: Mea suring, mapping and modelling: an integrated approach

595 to the management of mangrove and saltmarsh in the Minnamurra River estuary, southeast Australia, Wetl Ecol Manag, 20, $353-371,10.1007 / \mathrm{s} 11273-012-9258-2,2012$.

Reef, R., Schuerch, M., Christie, E. K., Moller, I., and Spencer, T.: The effect of vegetation height and biomass on the sediment budget of a European saltmarsh, Estuar Coast Shelf S, 202, 125-133,10.1016/j.ecss.2017.12.016,2018.

Riccardi, G.: A cell model for hydrological-hydraulic modeling, Journal of EnvironmentalHydrology, 8, 1-13, 2000.

600 Rodriguez, A. B., McKee, B. A., Miller, C. B., Bost, M. C., and Atencio, A. N.: Coastalsedimentation across North America doubled in the 20(th) century despite river dams, Nat Commun, 11, 10.1038/s41467-020-16994-z, 2020.

Rodriguez, J. F., Saco, P. M., Sandi, S., Sa intilan, N., and Riccardi, G.: Potential increase in coastalwetland vulnerability to sea-level rise suggested by considering hydrodynamic attenuation effects, Nat Commun, 8, ARTN 16094 $10.1038 /$ ncomms $16094,2017$.

605 Rogers, K., Wilton, K. M., and Saintilan, N.: Vegetation change and surface elevation dynamics in estuarine wetlands of southeast Austra lia, Estuar Coast Shelf S, 66, 559-569,10.1016/j.ecss.2005.11.004, 2006.

Rogers, K., Saintilan, N., and Copeland,C.: Modelling wetland surface elevation dynamics and its application to forecasting the effects of sea-level rise on estuarine wetlands, Ecol Model, 244, 148-157, 10.1016/j.ecolmodel.2012.06.014,2012.

Rogers, K., Sa intilan, N., and Copeland, C.: Reprint of Modelling wetland surface elevation dynamics and its application to

610 forecasting the effects of sea-level rise on estuarine wetlands, Ecol Model, 264, 27-36, 10.1016/j.ecolmodel.2013.04.016, 2013. 
Saco, P., and Rodríguez, J.: Modeling Ecogeomorphic Systems, in: Treatise on Geomorphology, edited by: Shroder, J. F., Elsevier Inc., San Diego, 201-220,2013.

Saco, P. M., Rodríguez, J. F., Moreno-de las Heras, M., Keesstra, S., Azadi, S., Sandi, S., Baartman, J., Rodrigo-Comino, J.,

615 and Rossi, J.: Using hydrological connectivity to detect transitions and degradation thresholds: Applications to dryland systems, Catena, 186, 10.1016/j.catena.2019.104354,2019.

Saintilan, N., Wilson, N. C., Rogers, K., Rajkaran, A., and Krauss, K. W.: Mangrove expansion and salt marsh decline at mangrove poleward limits, Global Change Biol, 20,147-157,10.1111/gcb.12341,2014.

Saintilan, N., Khan, N. S., Ashe, E., Kelleway, J. J., Rogers, K., Woodroffe, C. D., and Horton, B. P.: Thresholds of mangrove

620 survival under rapid sea level rise, Science, 368, 1118-+, ARTN aba2656

10.1126/science.aba2656,2020.

Sandi, S. G., Rodriguez, J. F., Saintilan, N., Riccardi, G., and Saco, P. M.: Rising tides, rising gates: The complex ecogeomorphic response of coastal wetlands to sea-level rise and human interventions, Adv Water Resour, 114, 135-148, 10.1016/j.advwatres.2018.02.006,2018.

625 Sandi, S. G., Saco, P. M., Saintilan, N., Wen, L., Riccardi, G., Kuczera, G., Willgoose, G., and Rodriguez, J. F.: Detecting inundation thresholds for dryland wetland vulnerability, Adv Water Resour, 128, 168-182, 10.1016/j.advwa tres.2019.04.016, 2019.

Sandi, S. G., Rodriguez, J. F., Saintilan, N., Wen, L., Kuczera, G., Riccardi, G., and Saco, P. M.: Resilience to drought of dryland wetlands threatened by climate change, Sci Rep-Uk, 2020a.

630 Sandi, S. G., Saco, P. M., Rodriguez, J. F., Saintilan, N., Wen, L., Kuczera, G., Riccardi, G., and Willgoose, G.: Patch organization and resilience of dryland wetlands, Sci Total Environ, 726, ARTN 138581

10.1016/j.scitotenv.2020.138581,2020b.

Schuerch, M., Spencer, T., Temmerman, S., Kirwan, M. L., Wolff, C., Lincke, D., McOwen, C. J., Pickering, M. D., Reef, R., Vafeidis, A. T., Hinkel, J., Nicholls, R. J., and Brown, S.: Future response of global coastalwetlands to sea-level rise, Nature,

635 561, 231-+, 10.1038/s41586-018-0476-5,2018.

Silvestri, S., Defina, A., and Marani, M.: Tidal regime, salinity and salt marsh plant zonation, EstuarCoast Shelf S, 62, 119130, 10.1016/j.eess.2004.08.010,2005.

Tabak, N. M., Laba, M., and Spector, S.: Simulating the Effects of Sea Level Rise on the Resilience and Migration of Tidal Wetlands a long the Hudson River, Plos One, 11, ARTN e 0152437

640 10.1371/journal.pone.0152437,2016.

Temmerman, S., Govers, G., Wartel, S., and Meire, P.: Spatialand temporalfactors controlling short-term sedimentation in a salt and freshwater tidal marsh, Scheldt estuary, Belgium, SW Netherlands, Earth Surf Proc Land, 28, 739-755, 10.1002/esp.495,2003.

Temmerman, S., Bouma, T. J., Govers, G., Wang, Z. B., De Vries, M. B., and Herman, P. M. J.: Impact of vegetation on flow

645 routing and sedimentation patterns: Three-dimensionalmodeling for a tidal marsh, J Geophys Res-Earth, 110, Artn F04019 $10.1029 / 2005 \mathrm{jf} 000301,2005$.

Temmerman, S., Moonen, P., Schoelynck, J., Govers, G., and Bouma, T. J.: Impact of vegetation die-off on spatial flow patterns over a tidal marsh, Geophys Res Lett, 39, Artn L03406

$10.1029 / 2011 \mathrm{gl} 050502,2012$.

650 Temmerman, S., and Kirwan, M. L.: Building land with a rising sea, Science, 349, 588-589, 10.1126/science.aac8312, 2015. Thorne, J. H., Choe, H., Stine, P. A., Chambers, J. C., Holguin, A., Kerr, A. C., and Schwartz, M. W.: Climate change vulnerability a ssessment of forests in the Southwest USA, Climatic Change, 148, 387-402, 10.1007/s1 0584-017-2010-4, 2018. Tian, B., Wu, W. T., Yang, Z. Q., and Zhou, Y. X.: Drivers, trends, and potential impacts of long-term coastal recla mation in China from 1985 to 2010, Estuar Coast Shelf S, 170, 83-90, 10.1016/j.ecss.2016.01.006, 2016.

655 Van Loon-Steensma, J. M., Van Dobben, H. F., Slim, P. A., Huiskes, H. P. J., and Dirkse, G. M.: Does vegetation in restored salt marshes equal natura lly developed vegetation?, Appl Veg Sci, 18, 674-682, 10.1111/avsc.12182,2015.

Williams, R. J., and Watford,F. A.: Identification of structures restricting tidalflow in New South Wales, Australia, Wetl Ecol Manag, 5, 87-97, 10.1023/A:1008283522167, 1997.

Woodroffe, C. D., Rogers, K., McKee, K. L., Lovelock, C. E., Mendelssohn, I. A., and Saintilan, N.: Mangrove Sedimentation

660 and Response to Relative Sea-Level Rise, Annu Rev Mar Sci, 8, 243-266, 10.1146/annurev-marine-122414-034025, 2016. 


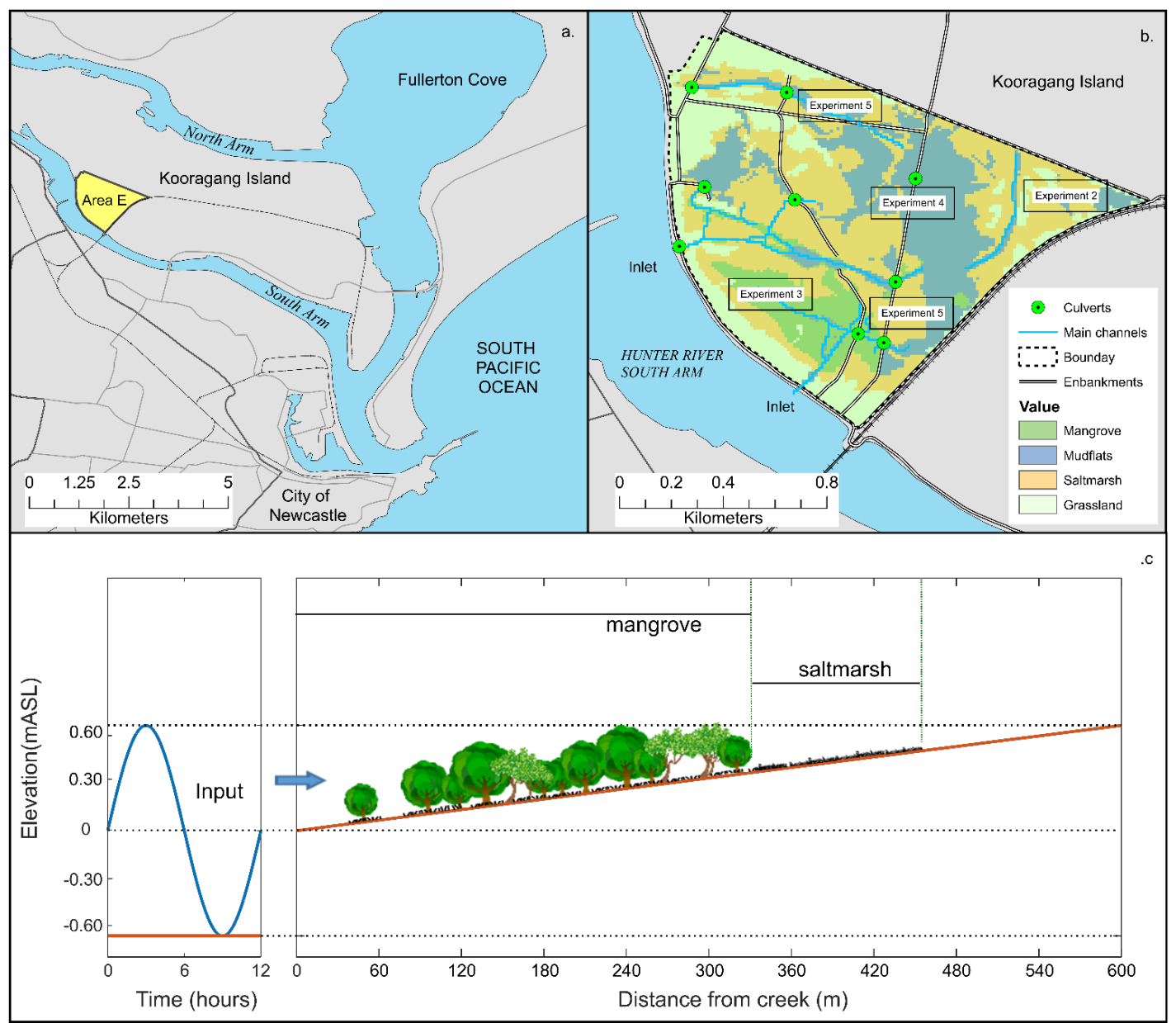

Figure 1. Field site and areas within the site characterised by the numerical experiments: a) Area $\mathbf{E}$ of Kooragang wetlands, b) areas within the wetland were the simplified experiments represent the dominant processes, c) schematic of the experimental setup corresponding to Experiment 2. The other experiments have a similar setup but incorporate more local features like an internal drainage channel and an embankment with a culvert. Adapted from Rodriguez et al. (2017)

Table 1: Parameters of soil surface elevation model

\begin{tabular}{|l|l|l|}
\hline Model Parameter & Mangrove & Saltmarsh \\
\hline$a\left(\mathrm{~g} / \mathrm{m}^{4}\right)$ & $-6,037.6$ & $-16,767$ \\
\hline$b\left(\mathrm{~g} / \mathrm{m}^{3}\right)$ & $7,848.9$ & 8,384 \\
\hline$c\left(\mathrm{~g} / \mathrm{m}^{2}\right)$ & $-1,328.3$ & 0 \\
\hline$q\left(\mathrm{~m}^{3} /\right.$ year $\left./ \mathrm{g}\right)$ & $9 \times 10^{-5}$ & $9 \times 10^{-5}$ \\
\hline$k\left(\mathrm{~m}^{5} / \mathrm{g}^{2}\right)$ & $1.2 \times 10^{-7}$ & $6.2 \times 10^{-7}$ \\
\hline
\end{tabular}




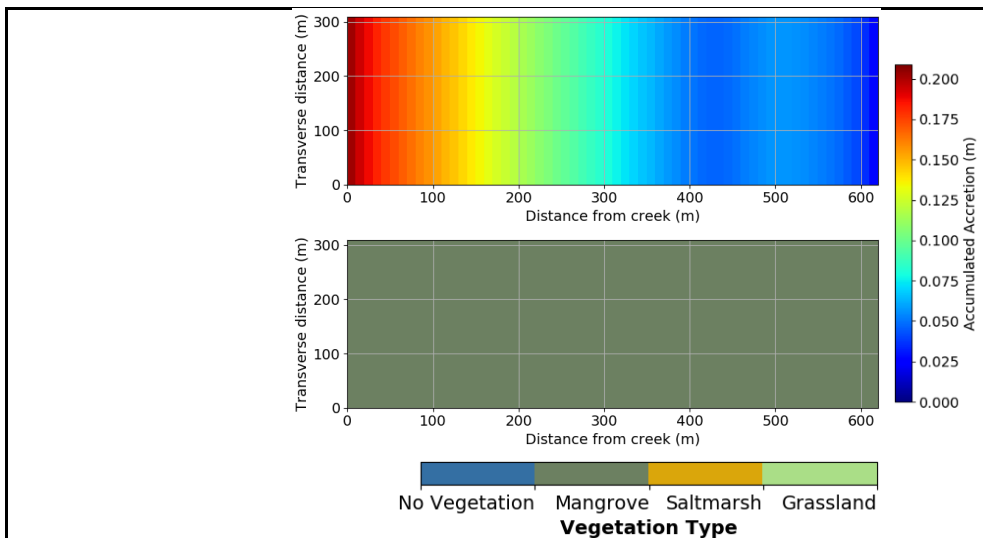

(a) Experiment 1: Bathtub
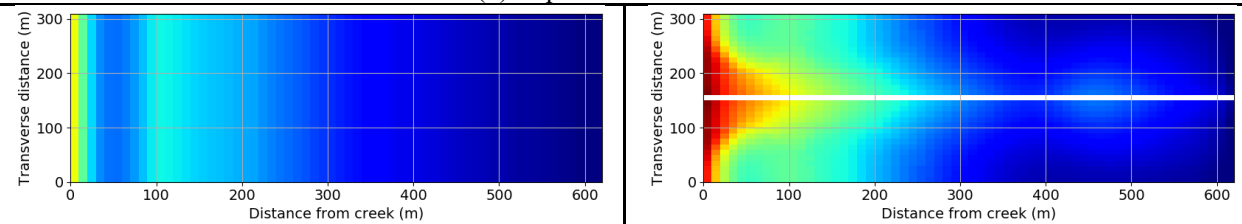

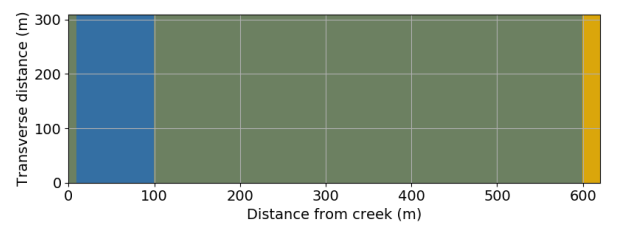

(b) Experiment 2:Free tidal flat
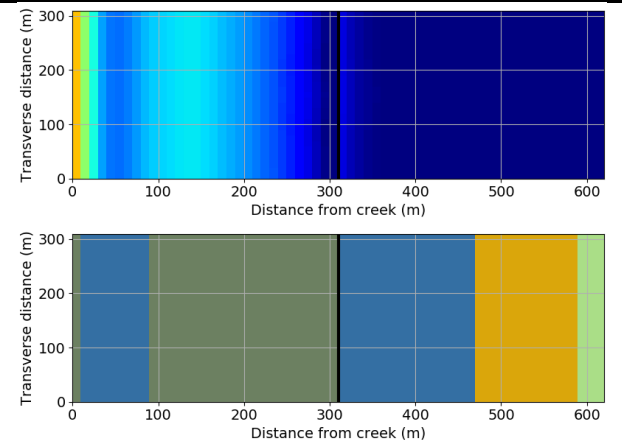

(d) Experiment 4:Embankment w/ culvert

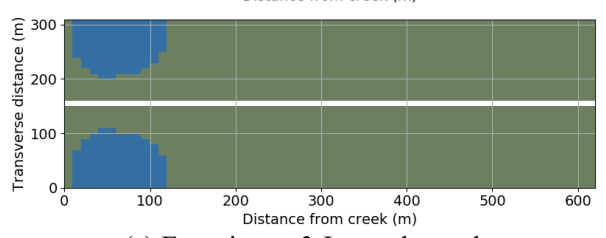

(c) Experiment 3:Innerchannel
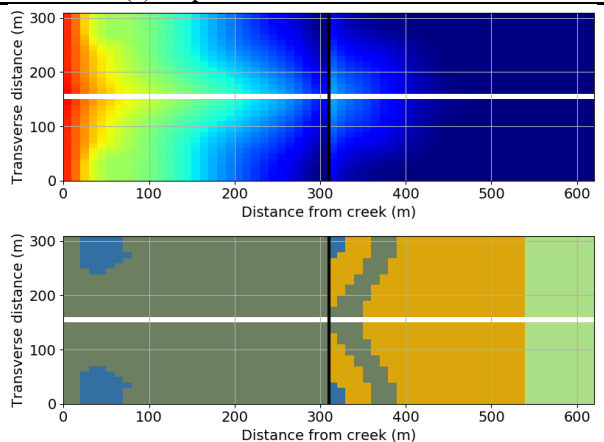

(e) Experiment 5:Embankment \& Inner channel

670 Figure 2. Accumulated accretion (top) and vegetation maps (bottom) in 2050 for low sediment input corresponding to: a) Experiment 1, b) Experiment 2, c) Experiment 3, d) Experiment 4, e) Experiment 5. 

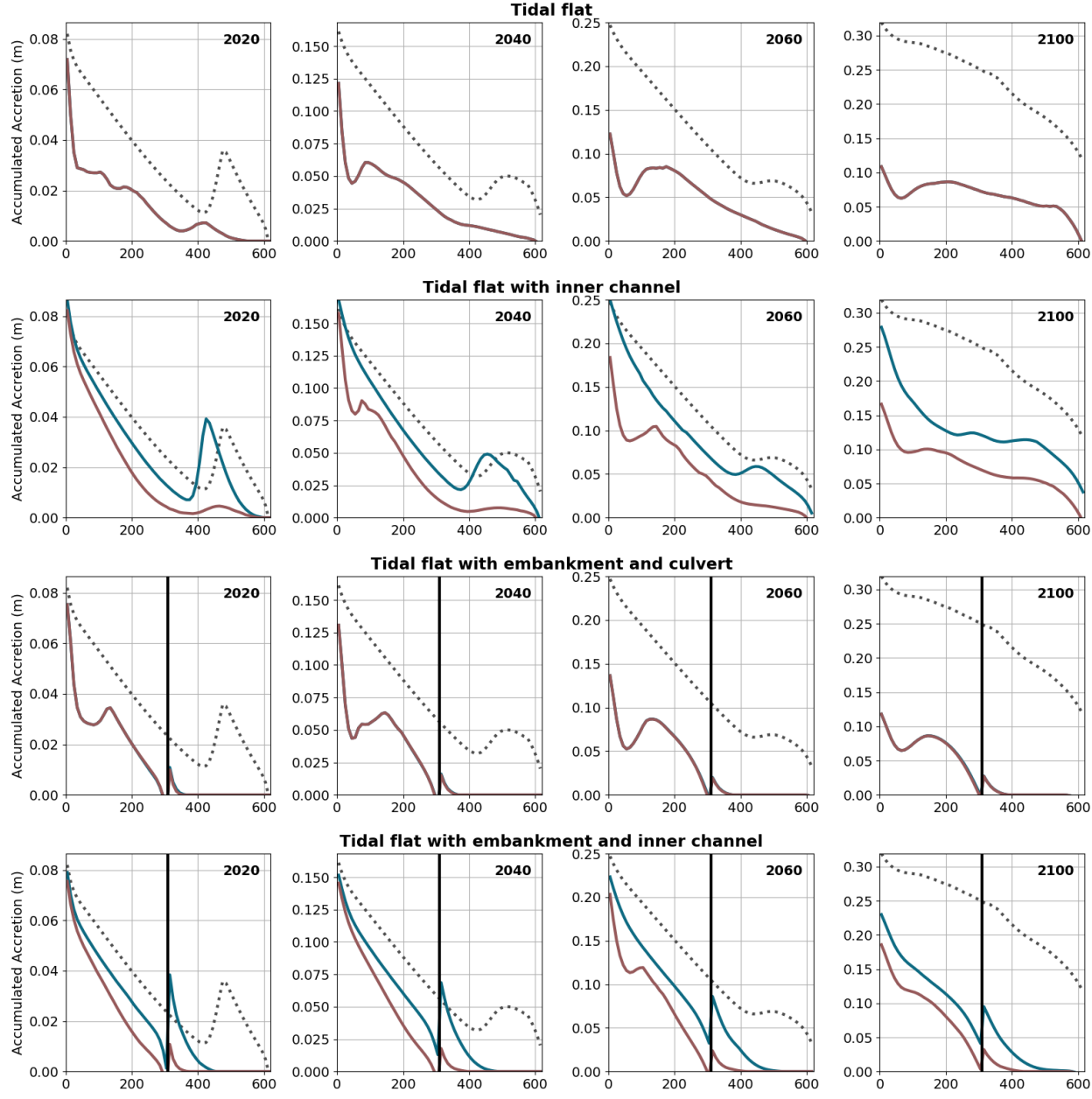

— floodplain

- channel

.. Bathtub

Figure 3. Longitudinal profiles of accumulated accretion $(\Delta \mathrm{E}, \mathrm{m})$ for a sediment supply of $37 \mathrm{~g} / \mathrm{m} 3$. The vertical black line represents the embankment with culvert. The "channel" profile represents the elevation gain near the central channel, while the "tidal flat" profile is situated in the middle of the tidal flat. 


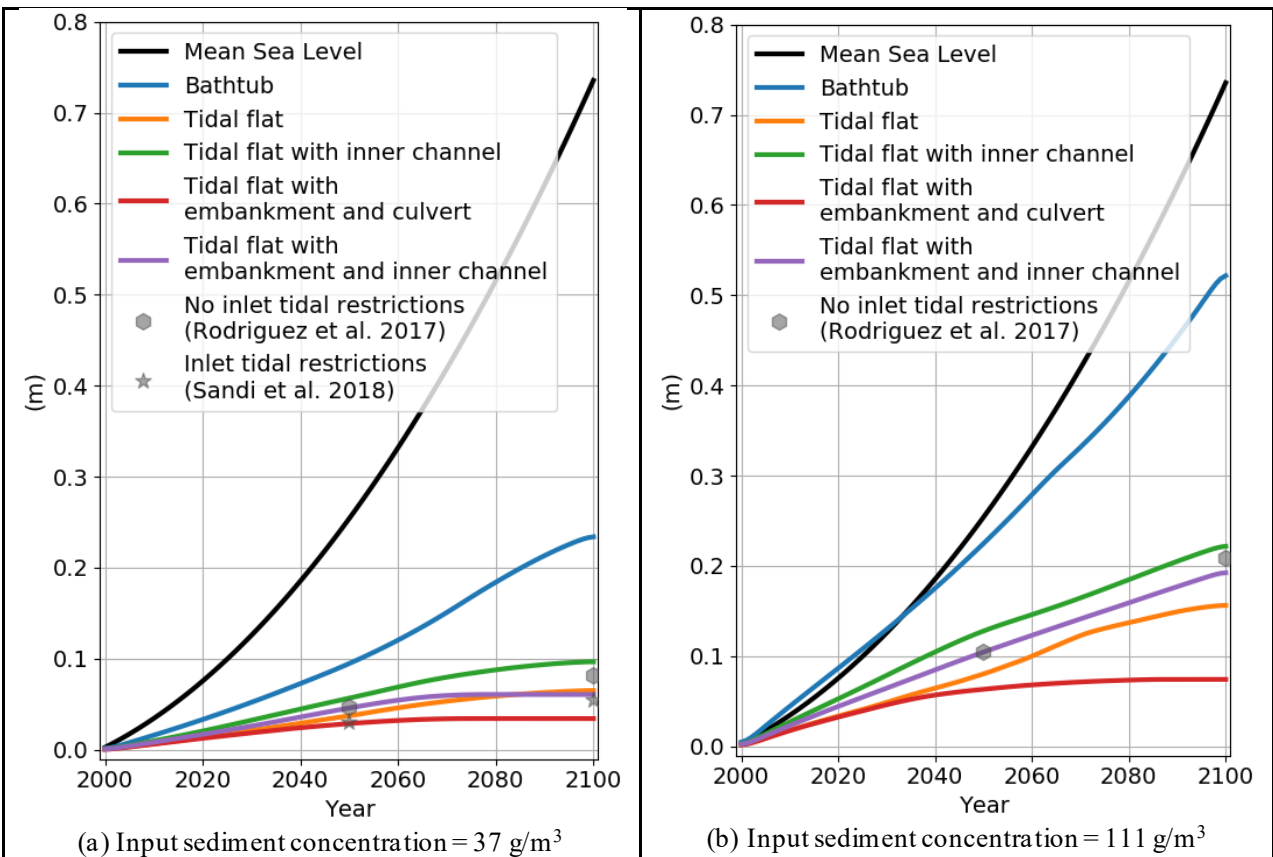

Figure 4. Sea-Level Rise and domain-average accumulated accretion over time for all experiments for a) low sediment input and b) high sediment input. Results from Rodriguez et al. (2017) and Sandi et al. (2018) corresponding to the entire Area $E$ wetland are included for comparison. 


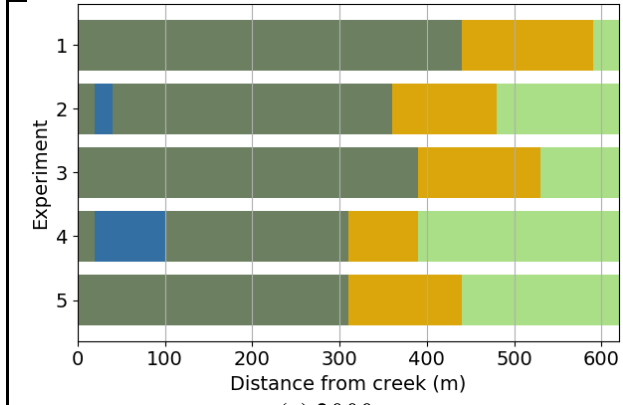

(a) 2000

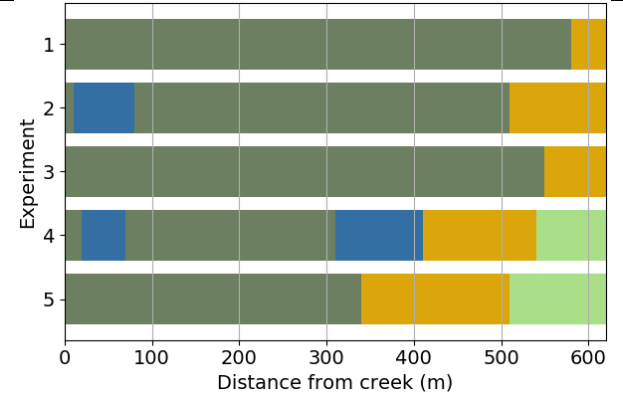

(c) 2040

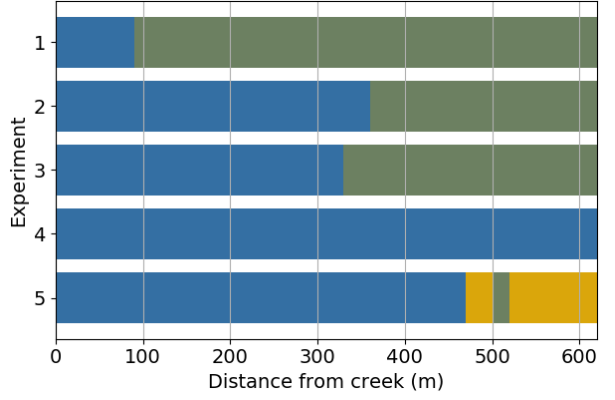

(e) 2080

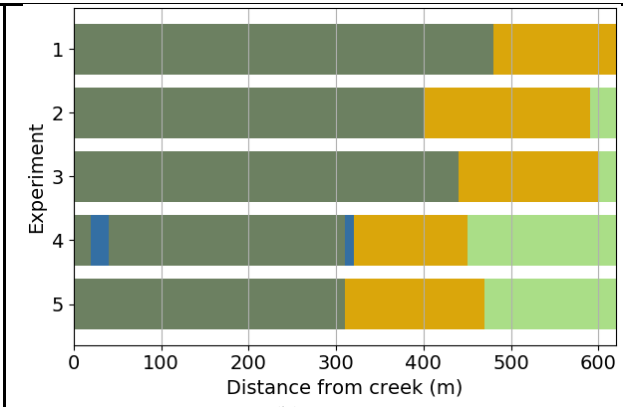

(b) 2020

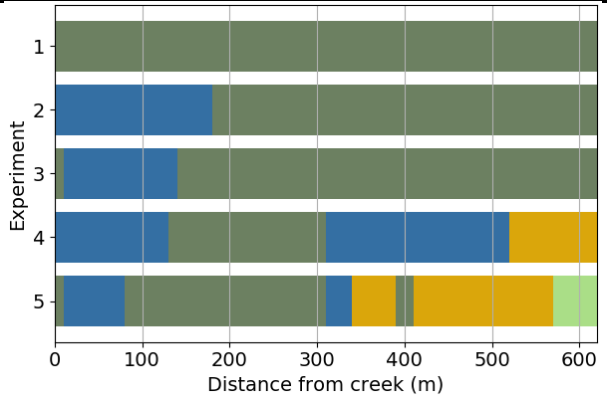

(d) 2060

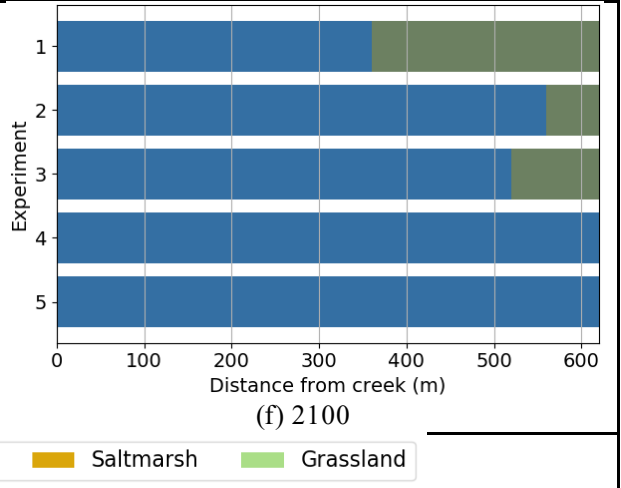

Figure 5. Predominant position occupied by each vegetation type in the tidal flat from 2000 to 2100 .Simulations for low sediment input, $\mathrm{SSC}=37 \mathrm{~g} / \mathrm{m} 3$. Experiments: 1 Bathtub, 2 Free tidal flat, 3 Inner channel, 4 Embankment with culvert and 5 Embankment and inner channel. 


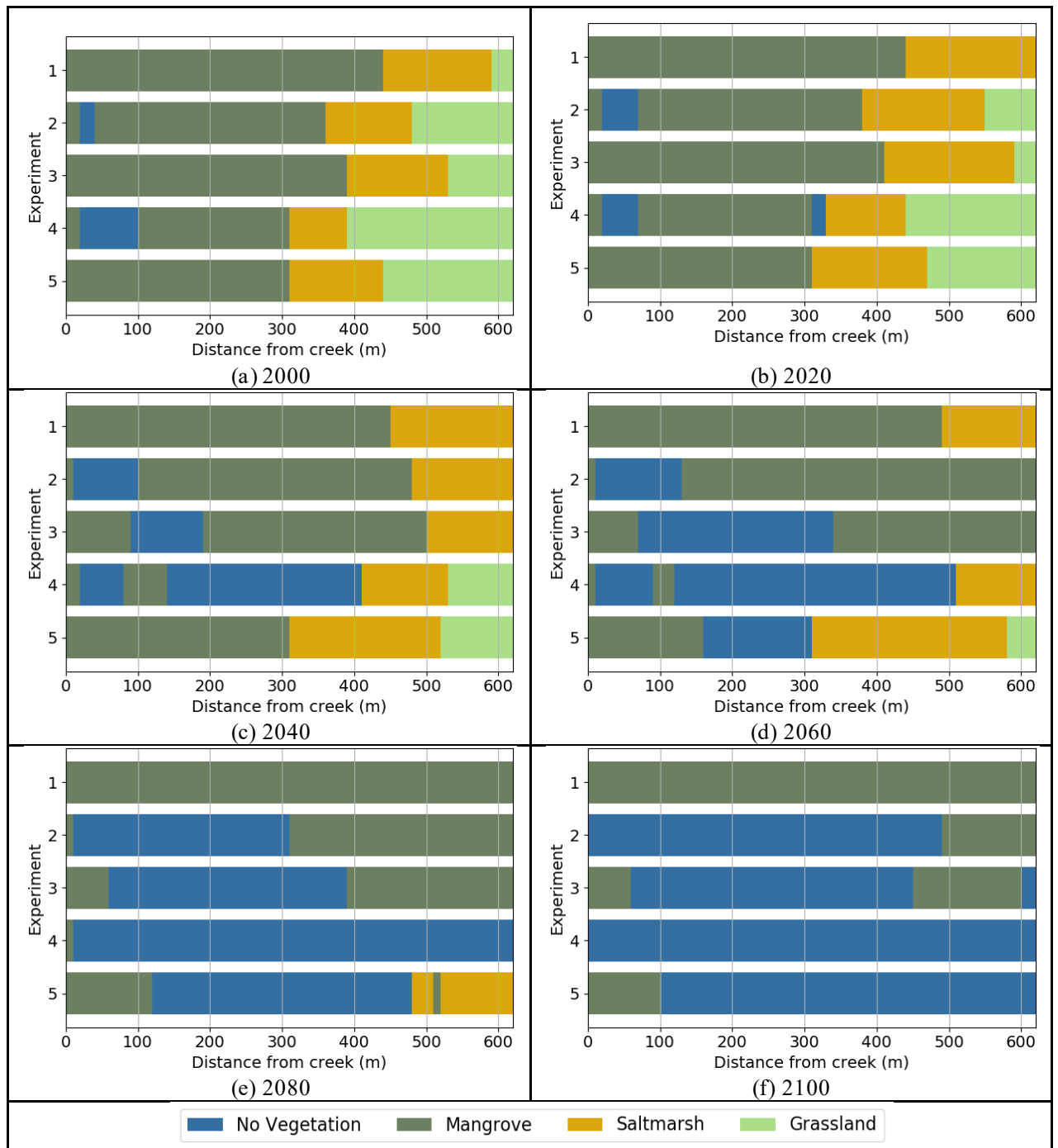

Figure 6. Predominant position occupied by each vegetation type in the tidal flat from 2000 to 2100 . Simulations for high sediment input, $\mathrm{SSC}=111 \mathrm{~g} / \mathrm{m} 3$. Experiments: 1 Bathtub, 2 Free tidal flat, 3 Inner channel, 4 Embankment with culvert and 5 Embankment and inner channel. 

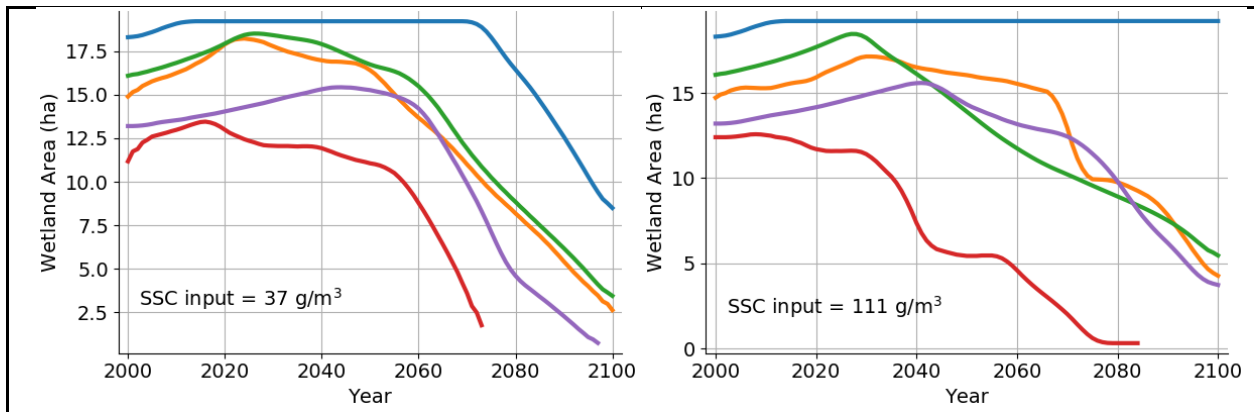

(a) Wetland area (mangrove + saltmarsh)
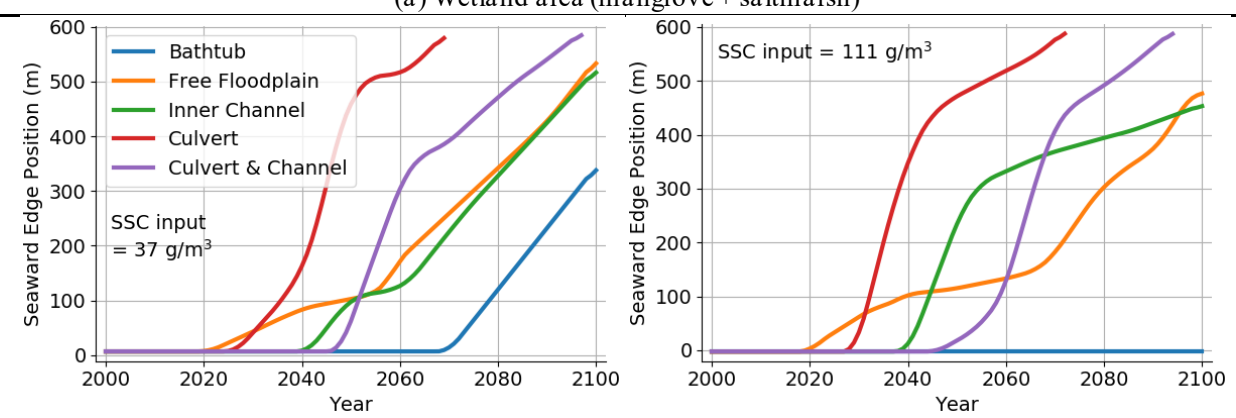

(b) Wetland retreat
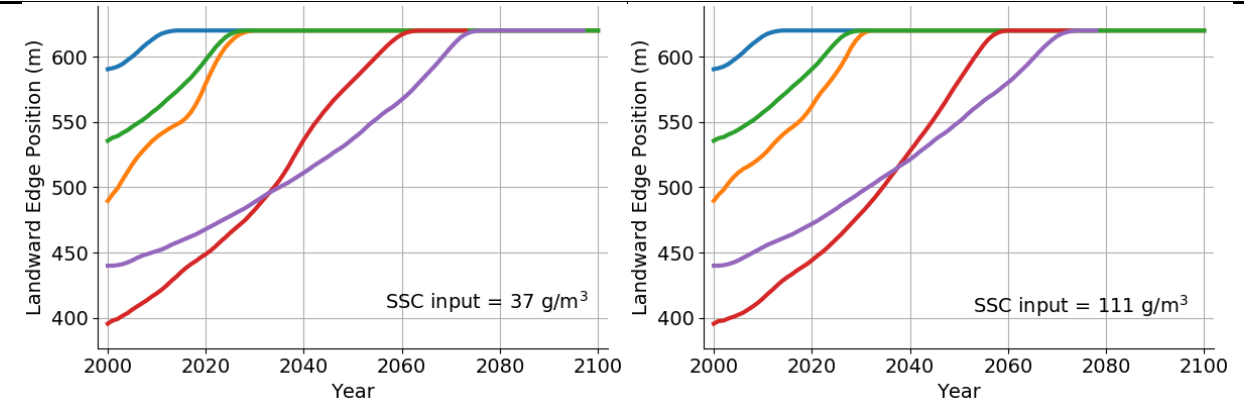

(c) Wetland transgression 